\section{Analysing the Cities' Inward Investment Promotion Websites}

\author{
Krzysztof Raganowicz \\ Maria Curie-Sktodoroska University in Lublin, Poland \\ krzysztof@raganowicz.eu
}

\author{
Analysing \\ the Cities' Inward \\ Investment \\ Promotion \\ Websites
}

\begin{abstract}
Purpose - This paper aims to answer the question of importance of the cities' investment promotion, and to analyse their inward investment promotion websites, which are the primary investment promotion tools. The analysis should identify common features of these websites, thereby indicate the crucial information from the point of view of target audiences.

Methodology - Inward investment promotion websites of four leading European cities (Barcelona, Manchester, Wrocław, and Lublin), concerning the foreign direct investment strategy, were analysed comparatively using an original tool based on the Website Attributive Evaluation System - City's Inward Investment Promotion Website Evaluation System.

Findings - The analysis showed that all four cities' websites are very similar in terms of the presented content. Moreover, the comparative approach to communication with investors is visible. However, there are significant differences in a graphic layout.

Research limitations - Only four websites were analysed comparatively. Hence, it is recommended to conduct similar research on a more significant sample.

Practical implications - The findings indicate that it can be possible to design transferable model of the city's inward investment promotion website.

Originality - An original tool was designed to analyse comparatively the cities' inward investment promotion websites.
\end{abstract}

Keywords - city marketing, investment marketing, website, business, city, Lublin, Manchester, Barcelona, Wrocław

\section{Introduction}

The modern global economy is facing a substantial shift consisting in rising importance of the cities and their functional urban areas at the cost of countries. Cites, as the centres of cultural and social life, tourism and entrepreneurship, are becoming the primary cores of economic development. One of the main fundamentals of local growth, apart from the locations that are merely based on tourist assets or education facilities, are domestic and foreign direct investments, which bring jobs, income to the city budget, and often improve the business image of the city. Therefore, big cities with strong local economies are made by the globalised world to compete against each other to convince the most progressive enterprises to choose them as a business location and to acquire the most prominent investments. To achieve these goals, cities extend their transport infrastructure, improve the quality of life, prepare business incentives, and carry out activities in the field of investment promotion.

\section{Psynergia}

International Journal of Synergy and Research

Vol. 6, 2017 pp. 149-161 
IJSR

6

This paper aims to answer the questions of importance of the cities' investment promotion, why inward investment promotion websites are used by the cities to promote their investment potential, and what consists of these websites. Moreover, it tries to indicate the crucial information that must be communicated towards potential investors and business analysts to draw their attention, thereby increasing the chance of the city to be chosen as the investment location. The core of the research was a comparative analysis of inward investment promotion websites of four leading European cities (Barcelona, Manchester, Wrocław, and Lublin) concerning the foreign direct investment strategy (fDi Magazine, 2016). The method used was the City's Inward Investment Promotion Website Evaluation System. The main idea was to check if it is possible to design perfectly transferable model of the city's inward investment promotion websites by the current best practices, or whether the ways of promoting city's investment potential are entirely different.

\section{Importance of the investment promotion of the cities}

According to one of the most acknowledged and comprehensive research, regarding investment promotion published by Wells and Wint (2000), it is defined as "activities that disseminate information about, or attempt to create an image of the investment site and provide investment services for the prospective investor" (Wells, Wint, 2000, p. 4). It does not cover all activities through which authorities try to attract investments, e.g. investment incentives or negotiations with investors, but the certain list of various types of activity from all fields of promotion-mix: "advertising, direct mailing, investment seminars, investment missions, participation in trade shows and exhibitions, distribution of literature, one-to-one direct marketing efforts, preparation of itineraries for visits of prospective investors, matching prospective investors with local partners, acquiring permits and approvals from various government departments, preparing project proposals, conducting feasibility studies, and providing services to the investor after projects have become operational" (Wells, Wint, 2000, p. 16), broadened with online types of promotion that developed in the $21^{\text {st }}$ century.

Many determinants influence the decision process regarding the choice of investment location. They consist of economic ones, e.g. market size, labour market, strategic assets and technology, and also business facilitation, which includes investment promotion activities. It plays a less prominent role than economic factors, but still, it is a significant policy instrument (Lim, 2008). It was proven that investment promotion might be a costeffective way of increasing FDI inflows - according to Investment Promotion Agency Czech Invest's data on expenditures on investment promotion and the realised investment projects in the Czech Republic, one USD of FDI inflows costs half a cent in investment promotion expenditures (Harding, Javorcik, 2011). What is more, investment promotion, as a factor that influences the overall attractiveness of a particular FDI destination, is easy to implement. On the other hand, economic factor changes (e.g. labour cost or market development) may be challenging and time-consuming (Lim, 2008).

Investment promotion was for a long time in the area of countries and regions' activities. However, the global, open economy, with less interrupted capital and trade flow, caused a significant increase in the role of cities in economic development. One 
of the most significant examples of this phenomenon is the position of cities in the European Union and precisely in the Single European Market (Metaxas 2010). With somewhat similar economic conditions of the countries in the EU and with particular financial incentives limited by the common European law, the business offer created by the urban regions is often the most critical factor that provides the added value that is decisive in the investment process. Cities form their business offers by having influence over local taxes, infrastructure, industrial estates and offices development, quality of life, and overall attractiveness of the city. On that account, the real competition during the process of investment location choice is between the offers provided by the cities, and so it requires specific forms of investment promotion realised by internal or external city investment promotion agencies.

The rapid development of information and communications technology allowed to harness sophisticated Internet tools to promote the investment offer (Makombe, Kachwamba, 2011). It is eminently essential in the times of broad access to the Internet and the diffusion of mobile communication devices. The time spent online is notably longer each year, and it is becoming ordinary that the majority of people use the Internet to find necessary information. It is exemplified with the research conducted by Molina et al. (2017) on the city branding regarding its tourist image $-77.8 \%$ of surveyed used online media when searching and planning their trips, and only $22.2 \%$ used offline media. It can be assumed that the use of online media to search for information on potential investment locations is similar. Now, the knowledge of the city's economic situation and its advantages and disadvantages is available regardless of place and time for anyone who needs to get it. In other words, the utilisation of the Internet can well meet the information demands of investors in a fast, easy and accurate way from all directions and levels (Hu, Lin, 2007). Hence, cities can use online promotion tools, e.g. websites, blogs, social media presence, or banner ads, for providing information to their target groups: entrepreneurs, business analysts, or representatives of trade organisations (Lozada, Kritz, 2007). It allows them to reach with information their target groups' members faster than their market competitors and, finally, to acquire the investment. Therefore, it plays a significant role in the first stages of the decision-making process, when the shortlist of potential business locations is chosen (Hardin, Javorcik, 2011).

\section{City's online investment promotion tools}

Four leading European cities, concerning the foreign direct investment (FDI) strategy, were chosen to distinguish the tools of online promotion used by cities in their investment promotion activities and then to analyse comparatively inward investment promotion websites, assuming that one of the factors of their success in terms of FDI is very efficient city marketing. The fDi Magazine (2016) European Cities \& Regions of the Future 2016/2017 ranking, divides cities into four categories: major cities, large cities, mid-sized cities and small cities. To conduct the analysis, one city from the leading three, from each group, was chosen: Barcelona (Spain) from the group of major cities, Manchester (United Kingdom), from the group of large cities, Wrocław (Poland) from the group of mid-sized cities, and Lublin (Poland) from the group of small cities. 
IJSR

6

According to the examined cities, the tools of city online investment promotion can be divided into two groups regarding interactivity, interoperability, and the possibility for the active viewing of the content, which is precisely the Web 1.0 and Web 2.0 division. However, the basis of all online promotional activities is always the inward investment promotion website which provides all necessary information about the city's business offer. This was indicated by Hu and Lin (2008) in their suggestions about the plan of city investment promotion information network system building. The second step, after forming a Leading Group and designing the consolidate Network System, is forming "a unified city investment promotion propaganda website" (Hu, Lin, 2008, p. 1432). Also, the practice shows that one of the first tasks of government agencies responsible for investment promotion is setting up an investment promotion website (Clemen, 2006). All remaining tools are embedded in the information and visual system of the website. These are Web 1.0 ones that limit the addressees to the passive viewing of content: newsletters, downloadable documents and reports, online document repositories, infographics, animations, and videos. On the contrary, Web 2.0 tools are interactive and allow two-way communication with the target of promotional messages (Florek, 2011). These are all social media platforms that are used by the cities in their investment marketing: LinkedIn and Twitter, which are the most important for business audiences, and Facebook, YouTube and SlideShare. They support sharing economic information about the city a lot more efficiently than Web 1.0 tools and, what is more, encourage the representatives of the target groups to react on all that information immediately, which provides very significant feedback to the marketer.

\section{City's Inward Investment Promotion Website Evaluation System}

In order to analyse comparatively inward investment websites of Barcelona, Manchester, Wrocław, and Lublin, the qualitative method of evaluating both technical and substantive elements of the websites has been created. It is based on Website Attributive Evaluation System (WAES). WAES was developed by the Cyberspace Policy Research Group (CyPRG) of University of Arizona and George Mason University in 1997 and has been used to evaluate national-level public agency websites (La Porte et al., 2001).

WAES is a highly formalised evaluation instrument that uses simple binary criteria to build a nuanced picture of an organisation's transparency and interactivity in Web operations [I]. Transparency and interactivity are measured by examining a website in terms of five clusters of attributes for each category, comprised of 45 specific criteria about web operation structure and functioning. Criteria are divided into ownership, contacts/reachability, organisational information, issue information, and citizen consequences/responses clusters for transparency, and security and privacy, contacts/ reachability, organisational information, issue information and citizen consequences/ responses for interactivity. Each criterion is marked 0 or 1 . Despite it is 21 years since WAES has been developed, it is not obsolete, and it is still used to evaluate both public and non-governmental organisations' websites (Marjak, 2008; Porębski, 2011) in an original form and in modified ones. 
The designed method of comparative analysis of inward investment promotion websites - City's Inward Investment Promotion Website Evaluation System - is based on WAES by sharing its essential features: simplicity of binary criteria, division into clusters of criteria, and objectivity. The clusters of attributes and criteria are adjusted to the specificity of this kind of specialised websites. This method is comprised of five categories consisting of 40 specific criteria based on literature (Grieg-Gran, Edlund, 2008; Harding, Javorcik, 2011; Ilie, 2015; Kimelberg, Williams, 2013; Lataj, 2011). The first category is Informational Content, and it describes the information about the investment offer of the city provided to the target audiences in 15 selected criteria. The next category is Agency Information, whose five criteria indicate if the city investment promotion agency responsible for the site is transparent, shares contact information, and actively communicates with its stakeholders. The third category, Content Quality, includes five criteria assessing the quality of the information provided in the prior two categories. The penultimate is User Interaction, which in five criteria indicates the most important elements that allow two-way communication with users of the website. The last one comprises ten technical elements that are the most important for a welldesigned, functional, and modern website.

\begin{tabular}{|c|c|c|}
\hline \multicolumn{3}{|c|}{ City's Inward Investment Promotion Website Evaluation System } \\
\hline Category & Criterion & Scoring \\
\hline \multirow[t]{15}{*}{ Informational content } & A1: agglomeration profile & Marked 0-1 \\
\hline & A2: business environment & Marked 0-2 \\
\hline & A3: transportation and access & Marked 0-1 \\
\hline & A4: quality of life/social environment & Marked 0-1 \\
\hline & A5: labour market & Marked 0-1 \\
\hline & A6: innovation and R\&D potential & Marked 0-1 \\
\hline & A7: financial incentives & Marked 0-1 \\
\hline & A8: investment opportunities & Marked 0-2 \\
\hline & A9: administrative processes & Marked 0-1 \\
\hline & A10: strategic plans & Marked 0-1 \\
\hline & A11: country profile & Marked 0-1 \\
\hline & A12: comparison with other cities & Marked 0-1 \\
\hline & A13: testimonials & Marked 0-1 \\
\hline & A14: general info (news, events) & Marked 0-1 \\
\hline & A15: secondary resources & Marked 0-1 \\
\hline \multirow[t]{5}{*}{ Agency information } & B1: identity & Marked 0-1 \\
\hline & B2: contact information & Marked 0-1 \\
\hline & B3: personal contacts & Marked 0-2 \\
\hline & B4: corporate roles and support & Marked 0-1 \\
\hline & B5: social media presence & Marked 0-1 \\
\hline
\end{tabular}

Analysing the Cities' Inward Investment Promotion Websites 
Pobrane z czasopisma International Journal of Synergy and Research http://ijsr.journals.umcs.pl Data: 26/04/2023 17:11:15

154

IJSR

6

\begin{tabular}{lll}
\hline Content quality & \multicolumn{1}{l}{ C1: clarity of purpose } & Marked 0-2 \\
\cline { 2 - 3 } C2: credibility of information & Marked 0-2 \\
\hline & C3: currency of information & Marked 0-2 \\
\hline C4: use of graphics & Marked 0-1 \\
\hline C5: multilanguage & Marked 0-1 \\
\hline User interaction & D1: newsletter & Marked 0-1 \\
\hline D2: Facebook & Marked 0-1 \\
\hline D3: Linkedln & Marked 0-2 \\
\hline D4: $:$ witter & Marked 0-1 \\
\hline D5: document and video hosting services & Marked 0-1 \\
\hline Technical & E1: Responsive Web Design & Marked 0-2 \\
\hline E2: navigation ease & Marked 0-2 \\
\hline E3: reading ease & Marked 0-1 \\
\hline E4: web prominence & Marked 0-1 \\
\hline E5: two-way communication & Marked 0-1 \\
\hline E6: search engine & Marked 0-1 \\
\hline E7: downloads & Marked 0-2 \\
\hline E8: disability access & Marked 0-1 \\
\hline E9: no add-ons & Marked 0-1 \\
\hline E10: no errors & Marked 0-1 \\
\hline
\end{tabular}

Source: Own elaboration.

The main difference between WAES and the designed tool is the Major Criteria concept. These are ten most crucial factors of success of the inward investment promotion website. To distinguish them from the others, they have doubled weighting. "A2: business environment" and "A8: investment opportunities" deliver information about the most prosperous economic sectors in the city and describe potential convenient ways of investment there. "B3: personal contacts" allows the website's user - the representative of a potential investor or business analyst - to communicate with the person in the city investment promotion agency responsible for serving the specific inquiry directly. Three criteria from the Content Quality category are crucial for credibility and image of the whole website and, therefore, the agency itself. "D3: LinkedIn" indicates the need of using social media and especially LinkedIn, which is considered as the most business social media platform nowadays. The last three technical major criteria are "E1: Responsive Web Design", which is essential for mobile Internet devices, "E2: navigation ease", that is the most important factor of user experience, and "E7: downloads", which allow the user to use provided information in forms of reports, infographics, data sheets, etc. also being offline. Concluding, website evaluated using Modified WAES can get maximum 50 points. 


\section{Comparative analysis of inward investment promotion websites}

The comparative analysis was performed in June 2017 using City's Inward Investment Promotion Website Evaluation System and covered websites of four cities chosen according to their excellence in FDI strategy.

Barcelona is considered as the leading major European city regarding FDI strategy (fDi Magazine, 2016). However, its inward investment promotion website is not the best example of its kind. The biggest problem of Barcelona's website is complicated navigation that guides the user through three different sites: Meet Barcelona [II], Ajuntament de Barcelona [III], and Barcelona Activa [IV]. In spite of using so many pages, the amount of information presented is low and it is not always up to date. The site neither informs about investment opportunities, nor shares personal contacts of the internal investment promotion agency's team members. Moreover, it is not responsive, so it hinders any access from mobile devices. Last but not least, Barcelona does not communicate any general business activities that take place in the city. Hence, Barcelona got 31 score, and just 10 out of 20 regarding Major Criteria. However, it is worth mentioning that the site includes very detailed secondary resources: e.g. key sectors' folders and splendid "Welcome to Barcelona" guide, which were not marked separately.

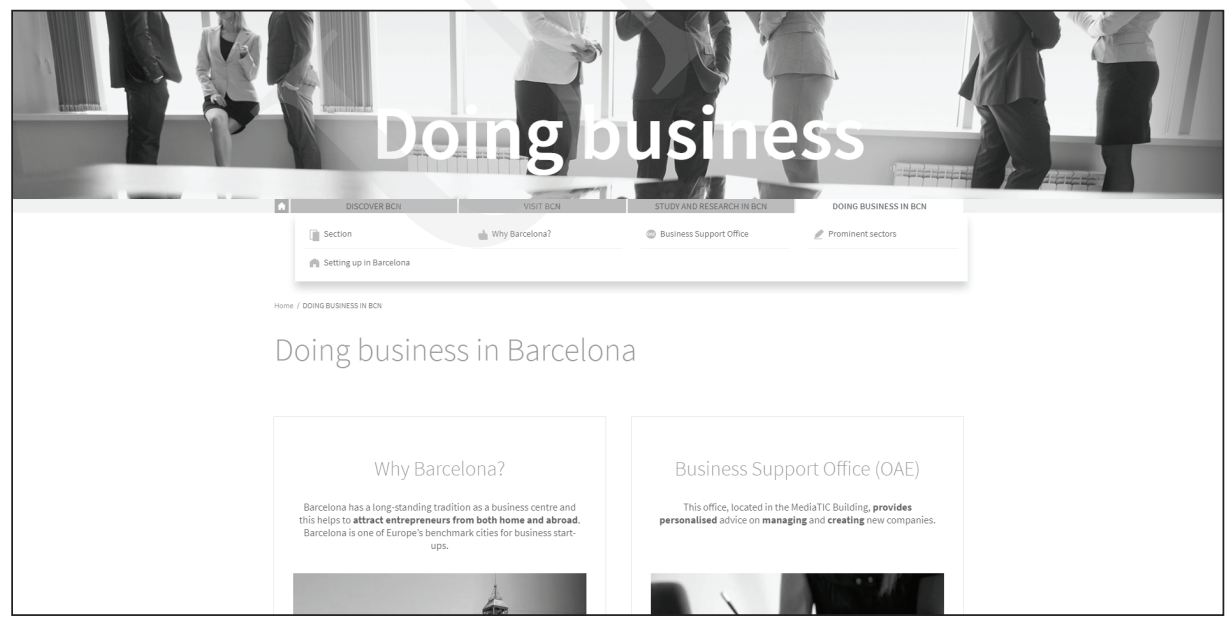

Source: Doing business in BCN [II]

Manchester, the leading large European city in terms of FDI strategy, has the newest website of the four analysed ones, which is reflected on the scorecard. It got 40 points, and 18 out of 20 concerning Major Criteria - it lost two points on the "B3: personal contacts" criterion because it provides only general contact information. Concluding, it is a very well-designed, modern, fully responsive website with excellent content quality, rich database of available properties and full business social media support. By the time of analysis, the site appeared to be still under construction, because, popular among other sites, image-building "testimonials" section was still empty.
Analysing the Cities' Inward Investment Promotion Websites

Figure 1. Website Meet Barcelona [II] 


\section{IJSR}

6

Figure 2.

Website

investinmanchester.com

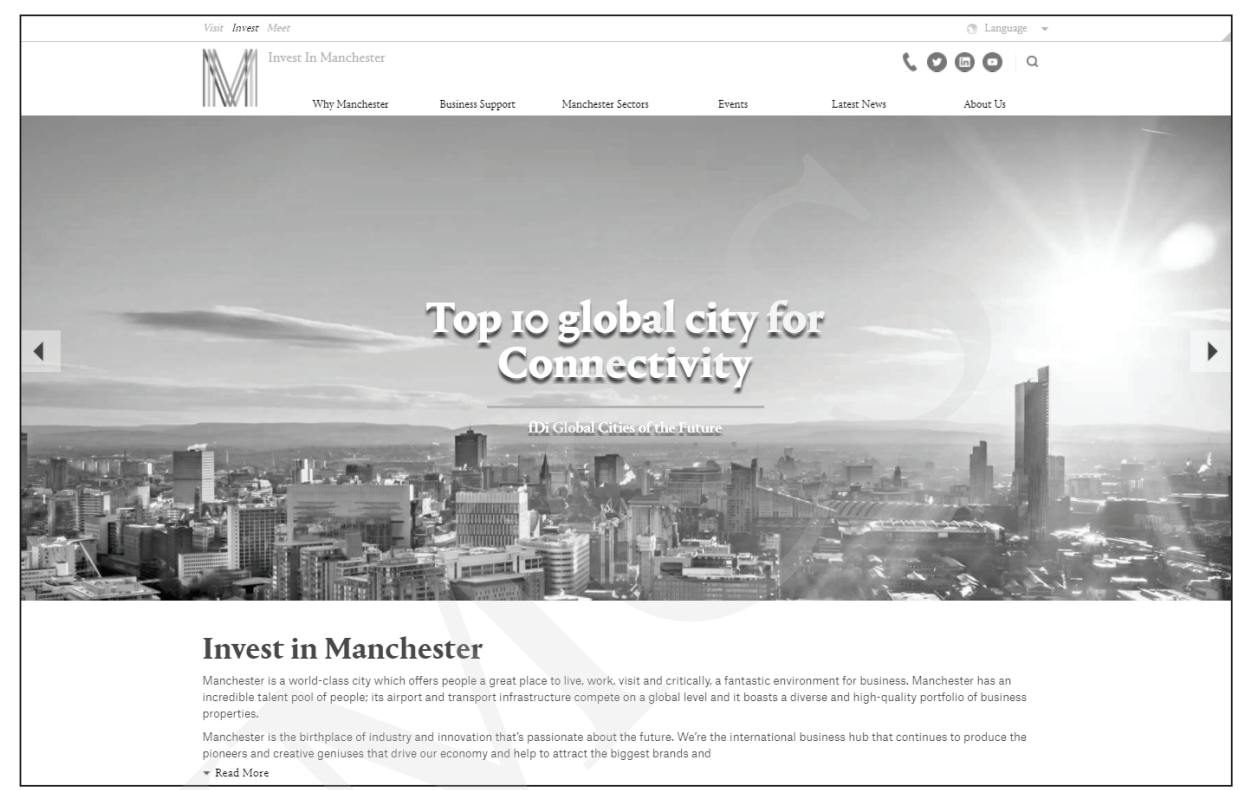

Source: www.investinmanchester.com

Wrocław, the city in south-western Poland, is one of the most rapidly developing cities in Poland and the European Union, thanks to its long-term FDI strategy, ranked $1^{\text {st }}$ among mid-sized European cities. Its inward investment website is a large project of the municipal investment agency and JP Weber consulting firm. It results in the abundance of data presented on the website, but it is outdated in some parts. What is unusual, the site provides a very rich database of potential investment locations both with suppliers available in the Wrocław region. A characteristic feature of the website is that the general info from the city - news, events, and publications - covers most of the main page. According to the score, Wrocław achieved 38 points and 14 points from Major Criteria. The site is not responsive, does not provide personal contact information, and the data is not completely up-to-date, but these drawbacks were over-compensated with the complexity of information.

The website which significantly differs visually from the compared ones belongs to the City of Lublin - invest-in-lublin.com. It is the best prepared for mobile devices site because of using fully responsive block design. The site provides all necessary information about the city and key sectors of the local economy, but it does not include general agency contact information. Instead, it is the only website that provides the full list of front office employees responsible for investor relations with detailed personal contacts. This approach is considered as thebest practice by Lataj (2011, p. 74) and Ilie (2015, p. 19). Moreover, Lublin puts a strong emphasis on social media user acquisition from LinkedIn, SlideShare and Twitter city accounts. Hence, it scored 20 points in Major Criteria category, and overall it got 38 points. Lublin's site lost points for lack of an on-site search engine, different language versions, and general contact information, which is considered as a standard feature. 
Pobrane z czasopisma International Journal of Synergy and Research http://ijsr.journals.umcs.pl Data: 26/04/2023 17:11:15

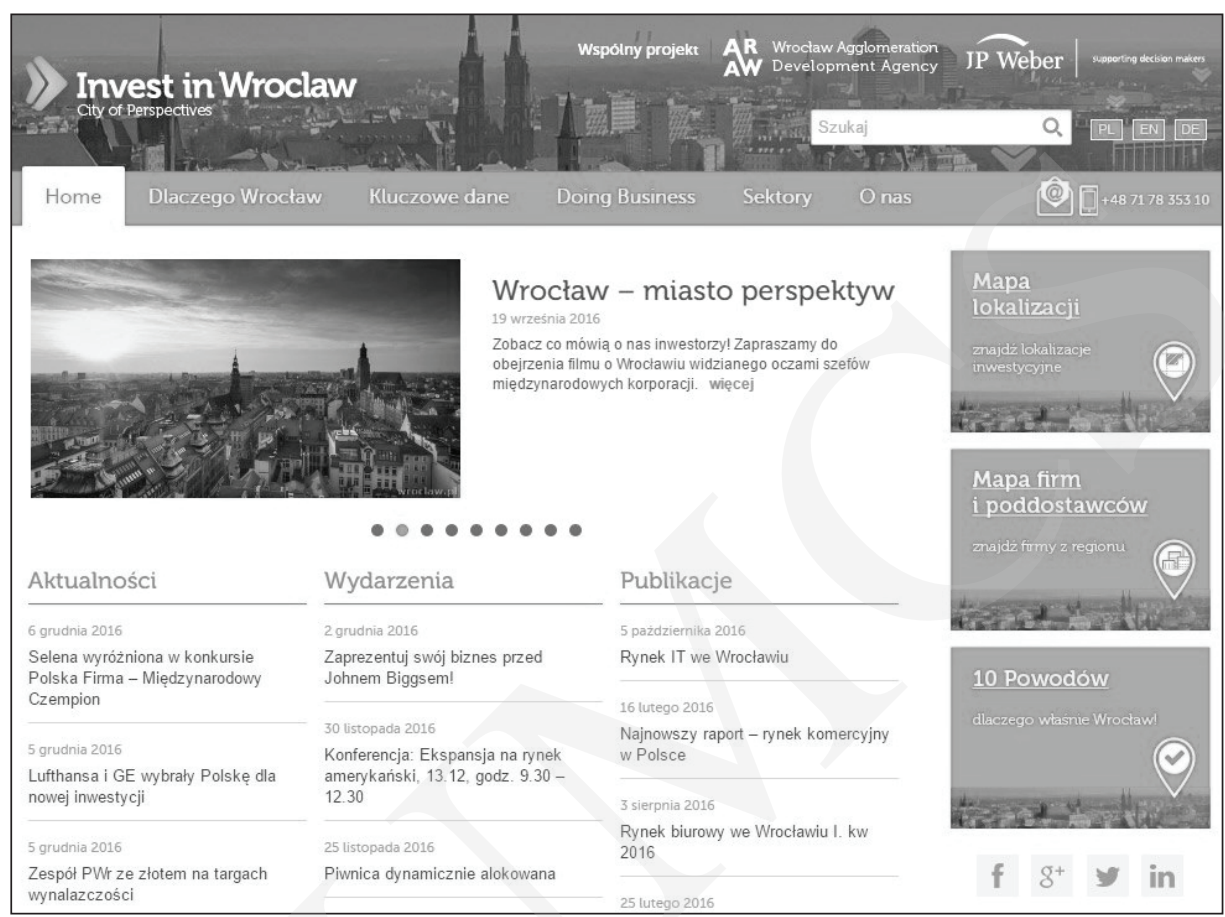

Analysing the Cities' Inward Investment Promotion Websites

Source: www.investinwroclaw.pl

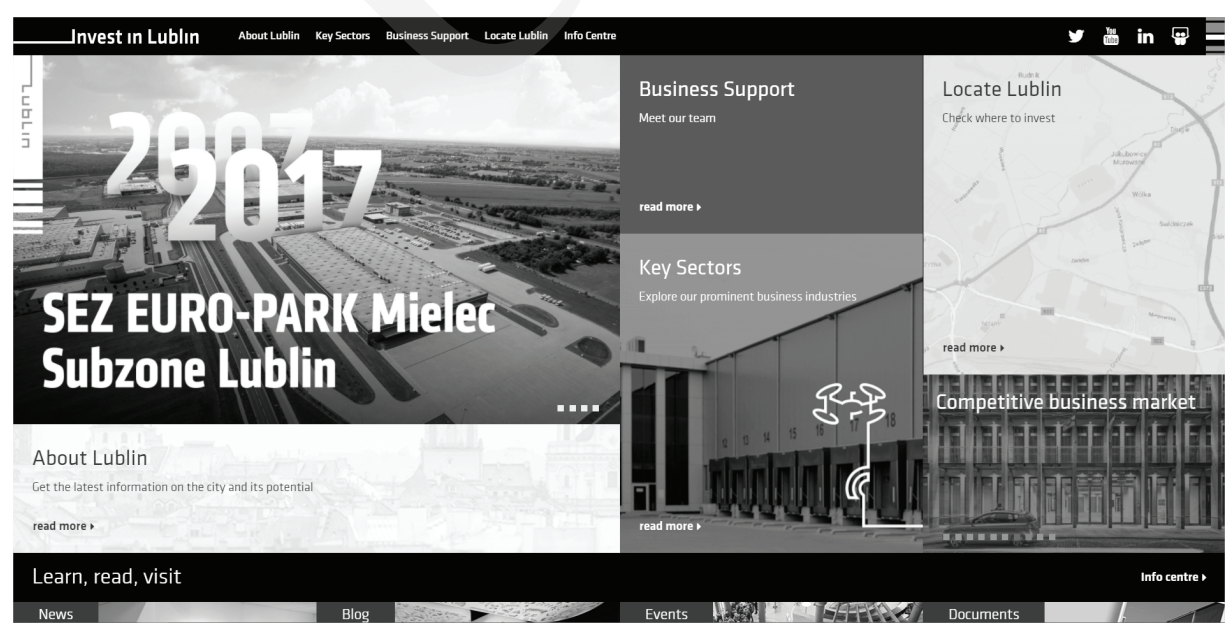

Figure 4.

Website invest-inlublin.com

Source: www.invest-in-lublin.com 
IJSR

6

Table 2.

Analysed websites' scores
The results of comparative analysis of four inward investment websites of Barcelona, Manchester, Wrocław, and Lublin are presented in Table 2. The site of Manchester achieved the highest overall score, and Lublin got the best results as the sum of Major Criteria points. However, the differences between the sites were not significant - there are a lot of similarities that suggest the existence of the common model of inward investment promotion design. All analysed websites provide very similar categories of information about the city - they always consist of agglomeration profile, business environment, transportation and access, quality of life, and innovation and R\&D potential. All sites use downloadable secondary information resources. On the other hand, they do not inform about the country profile, strategic plans, or they do not compare themselves with other cities, focusing only on the domestic location. In the cluster of "Agency Information", the only difference is the approach to personal contacts. All analysed websites have a clear inward investment attraction purpose and provide credible information about the city. The primary language is always English - for Lublin, it is even the only language used. This fits the observation of Harding and Javorcik (2011) that investment promotion is to alleviate information asymmetries. Hence, it is more effective in countries where English is not an official language. All cities use social media services: LinkedIn and Twitter, to interact with the representatives of their target groups. Only Wrocław uses Facebook for business communication, and only Barcelona uses the newsletter, which appears to be an obsolete tool of promotion now. Slightly more differences are in the technical category, where only two sites scored in the criterion of Responsive Web Design: Manchester and Lublin. Also, just two of them uses on-site dynamic scripts allowing two-way communication. Finally, the analysis has diagnosed one general problem. The cities forget about disabled people in their online investment promotion. None of the sites is using even elementary disabled-friendly mechanisms like colour or text size adjusting.

\begin{tabular}{lccccc}
\hline \multicolumn{1}{c}{ Category } & Score & Barcelona & Manchester & Wrocław & Lublin \\
\hline Informational content [A] & $\max 17$ & 8 & 12 & 14 & 12 \\
\hline Agency information [B] & $\max 6$ & 4 & 4 & 4 & 5 \\
\hline Content quality [C] & $\max 8$ & 6 & 8 & 6 & 7 \\
\hline User interaction [D] & $\max 6$ & 5 & 4 & 5 & 4 \\
\hline Technical [E] & $\max 13$ & 8 & 12 & 9 & 10 \\
\hline Major criteria & $\max 20$ & 10 & 18 & 14 & 20 \\
\hline Total & $\max 50$ & 31 & 40 & 38 & 38 \\
\hline
\end{tabular}

Source: Own elaboration. 


\section{Model of the city's inward investment promotion website design}

The similarities between inward investment promotion websites of the leading European cities regarding FDI strategy indicate that there is a particular design of such a website. It consists of specific elements that exist on each of the analysed sites. On the basis of the analysis, it is possible to show a model of this kind of website's design.

The model of city's inward investment promotion website design should comprise information about agglomeration profile, business environment, transportation and access, quality of life, innovation and R\&D potential, labour market, financial incentives, and investment opportunities. The internal or external investment promotion agency responsible for the city's investment promotion should be easy to identify. Information about the agency should consist of the corporate roles of the staff, all necessary contact data of each front office employee, and forms of support for investors. Moreover, it should be present in business social media - LinkedIn, Twitter - integrated into one informational and graphics system with the website. The content should be credible and up-to-date, graphics should be relevant, and the purpose of the site should be clear and focused on business needs. The primary operation language used on the site must be English to alleviate the problems associated with the lack of information. According to the technical requirements, the model website should be easy to navigate and use thanks to Responsive Web Design, to find by search engines, and to read by using regular fonts. It should offer downloadable secondary materials and access for disabled users. Finally, the site must be add-on free and error free. This design will allow every city to build its own inward investment promotion website that answers the business needs and will enhance the effectiveness of the city's investment promotion activities, which will result in attracting new investments.

\section{Conclusions}

Investment promotion is a significant determinant that influences the decision-making process regarding the choice of investment location because it is cost-effective and more accessible to implement than activities leading to economic factors change. Modern, globalised economy creates a possibility for the cities to carry out their investment promotion activities concomitantly with standard promotion activities of their countries and regions.

Cities use online marketing tools to promote online their investment business offer. The primary form of this promotional activity is a special inward investment promotion website, supported by business social media presence and on-site downloadable materials. This kind of website consists of certain parts that are common to all cities that carry out investment promotion activities. According to the four analysed sites of Barcelona, Manchester, Wrocław, and Lublin, the most crucial information that must be communicated towards potential investors and business analysts includes agglomeration profile, business environment, transportation and access, quality of life, innovation and R\&D potential, and the investment promotion agency's business support.

The method used in the study to analyse comparatively the websites - City's Inward Investment Promotion Website Evaluation System - may become a useful tool to evaluate

Analysing
the Cities' Inward
Investment
Promotion
Websites

Analysing

nvestment

Websites 
IJSR

6

their quality, structure, and technical features. However, the criteria applied in the method should be confronted with prospective research on the importance of business location factors and the effectiveness of marketing of the city's investment offer.

All compared websites have many common features in every analysed category. There is an evident similarity in the approach to the design and content of inward investment promotion website. Assuming the cities' expertise in investor service, proven by the highest positions in the strategy for attracting investors ranking of fDi Magazine, it indicates that it could be possible to design perfectly transferable scheme of the city's inward investment promotion website. On the other hand, the small research sample consisting of only four websites indicates the need to broaden the research to achieve more accurate results in designing a model of the investment promotion website.

\section{References}

Clemen, V. (2006). A Briefing for American Businesses Looking to Invest in Vietnam. Hastings Business Law Journal, vol. 2, no. 2, pp. 507-525.

fDi Magazine(2016). fDi Supplement: European Cities and Regions of the Future 2016/17. Retrieved February 3, 2018 from: https://www.fdiintelligence.com/Rankings/EuropeanCities-and-Regions-of-the-Future-2016-17

Florek, M. (2011). Online city branding. In: K. Dinnie (ed.), City Branding, Palgrave Macmillan UK, Basingstoke, pp. 82-90.

Grieg-Gran, M., Edlund, J. (2008), Attracting FDI that contributes to sustainable development: a review of current IPA practice. In: A. Dufey, M. Grieg-Gran, H. Ward (eds.), Responsible Enterprise, Foreign Direct Investment and Investment Promotion, IIED, London, pp. 17-27.

Harding, T., Javorcik, B.S. (2011). Roll out the red carpet and they will come: Investment promotion and FDI inflows. The Economic Journal, vol. 121, no. 557, pp. 1445-1476.

Hu, T., \& Lin, Y. (2008). A research on the building of city investment promotion information network system. In: L. Xu, A. Tjoa, S. Chaudhry (eds.), Research and Practical Issues of Enterprise Information Systems, II vol. 2, Springer, Boston, MA, pp. 1425-1433.

Ilie, G. (2015). Investment Promotion Tools and their Contribution in Attracting Foreign Direct Investments. Knowledge Horizons - Economics, vol. 7, no. 2, pp. 15-21.

Kimelberg, S.M., Williams, E. (2013). Evaluating the importance of business location factors: The influence of facility type. Growth and Change, vol. 44, no. 1, pp. 92-117.

La Porte, T.M., Demchak, C.C., Friis, C. (2001). Webbing governance: Global trends across national-level public agencies. Communications of the ACM, vol. 44, no. 1, pp. 63-67.

Lataj, J. (2011). Use Modern Information Technologies to Promote Foreign and Domestic Investment. International Journal of Interdisciplinary Research SIPARUNTON, vol. 1, no. 1, pp. $71-74$.

Lim, S.H. (2008). How investment promotion affects attracting foreign direct investment: Analytical argument and empirical analyses. International Business Review, vol. 17, no. 1, pp. 39-53.

Lozada, H.R., Kritz, G.H. (2007). Investment promotion agencies on the Internet: Evaluating promotion tactics and web presence. Journal of International Business Research, vol. 6, no. 2, pp. 17-31.

Makombe, I., Kachwamba, M. (2011). Internet marketing in the public sector: the case of investment promotion agencies. International Journal of eBusiness and eGovernment Studies, vol. 3, no. 2, pp. 79-89.

Marjak, H. (2008). Metody oceny i walidacji stron internetowych. Prace Naukowe. Szkoła 
Gtówna Gospodarstwa Wiejskiego. Wydział Nauk Ekonomicznych. Katedra Polityki Agrarnej i Marketingu, vol. 45, no. 1, pp. 355-367.

Metaxas, T. (2010). Cities competition, place marketing and economic development in South Europe: The Barcelona case as FDI destination. Theoretical and Empirical Researches in Urban Management, vol. 5, no. 14, pp. 5-19.

Molina, A., Fernandez, A.C., Gomez, M., Aranda, E. (2017). Differences in the city branding of European capitals based on online vs. offline sources of information. Tourism Management, vol. 58, pp. 28-39.

Porębski, L. (2011). Nowe technologie w funkcjonowaniu polskiego samorządu lokalnego: analiza zawartości witryn powiatów ziemskich. Nierówności Spoleczne a Wzrost Gospodarczy, vol. 22, pp. 128-140.

Wells, L.T., Wint, A. G. (2000). Marketing a country: promotion as a tool for attracting foreign investment. FIAS occasional paper, vol. 13.

\section{Notes}

[I] CyPRG: Website Attributive Evaluation System. Retrieved January 29, 2012 from: http:// www.cyprg.arizona.edu:80/waes.html

[II] Doing business in BCN. Retrieved February 6, 2018 from: http://meet.barcelona.cat/en/ doing-business

[III] Barcelona Business. Retrieved February 6, 2018 from: http://w42.bcn.cat/web/en/

[IV] Barcelona Activa. Retrieved February 6, 2018 from: https://empreses.barcelonactiva.cat/en/ 
